\title{
The relationship between milking interval and somatic cell count in automatic milking systems
}

\author{
H. Mollenhorst, ${ }^{* 1}$ M. M. Hidayat, ${ }^{*} \dagger$ J. van den Broek, ${ }^{*}$ F. Neijenhuis, $\neq$ and H. Hogeveen ${ }^{\star} \S$ \\ *Department of Farm Animal Health, Faculty of Veterinary Medicine, Utrecht University, PO Box 80151, 3508 TD Utrecht, the Netherlands \\ †Directorate General of Livestock and Animal Health, Ministry of Agriculture, PO Box 1108/JKS, Jakarta 12011, Indonesia \\ ¥Wageningen UR Livestock Research, PO Box 65, 8200 AB Lelystad, the Netherlands \\ $\S$ Business Economics Group, Wageningen University, PO Box 8130, 6700 EW Wageningen, the Netherlands
}

\begin{abstract}
The aim of this study was to explore whether, during automatic milking, milking interval or its variation is related to somatic cell count (SCC), even when corrected for effects of production, lactation stage, and parity. Data on milking interval and production level were available from the automatic milking systems of 151 farms. Data on SCC, parity, and lactation stage were derived from dairy herd improvement records of the same farms. Mainly due to incomplete records, data of 100 farms were used in the final analysis. For every cow, only 1 test day was used in the final analysis. Milking interval, the coefficient of variation of milking interval, production rate, the difference in production rate between short- and long-term, parity, days in milk, and some biologically relevant interactions were used in a linear mixed model with farm as random variable to assess their association with $\log 10$-transformed SCC. None of the interactions was significantly related to SCC, whereas all main effects were, and thus, stayed in the final model. The effect of milking interval was, although significant, not very strong, which shows that the effect of milking interval on SCC is marginal when corrected for the other variables. The variation in milking intervals was positively related with SCC, showing that the variation in milking interval is even more important than the milking interval itself. In the end, this study showed only a limited association between milking interval and SCC when milking with an automatic milking system.
\end{abstract}

Key words: automatic milking system, milking interval, somatic cell count

\section{INTRODUCTION}

Milking intervals vary considerably between cows and between farms when milking with an automatic milk-

\footnotetext{
Received February 7, 2011.

Accepted May 25, 2011.

${ }^{1}$ Corresponding author: h.mollenhorst@uu.nl
}

ing system (AMS). Cows can be milked about 3 times per day, whereas some cows will only visit the AMS again after more than a 12-h interval. Only limited knowledge exists about the effect of milking intervals on SCC and most knowledge originates from conventional milking systems with fixed intervals. Changing from twice- to once-daily milking lowered milk production and increased SCC (Stelwagen and Lacy-Hulbert, 1996). On the other hand, very short intervals (less than $8 \mathrm{~h}$ ) may be problematic as well, as teats do not have enough time to recover (Neijenhuis et al., 2001), which may increase udder health problems in the long run. When milking intervals (in the short-term) were decreased even more to $6 \mathrm{~h}$, SCC increased in milk from healthy as well as unhealthy quarters (Nielsen et al., 2005). In fact, the lowest SCC were shown with milking intervals between 8 and $10 \mathrm{~h}$ (Fernando and Spahr, 1983). All of these studies, however, tested only the short-term effect of milking intervals. Long-term effects of short milking intervals on udder health were only studied for changing from milking 2 times per day to 3 times per day. Somatic cell count seemed to decrease for cows of parity 1 to 3 , whereas it increased for cows of parity 4 and higher (Allen et al., 1986). In another study, however, no effect of milking 2 or 3 times per day could be found (Österman et al., 2005). Knowledge about the effects of milking intervals in AMS is very limited. Friggens and Rasmussen (2001) concluded that a linear correction has to be applied for difference in milk production, which is mainly determined by difference in milking interval, to adjust SCC values of single milk samples to represent daily average SCC. Samples taken after a short milking interval otherwise would underestimate the daily average SCC. That study, however, focused on within-cow effects, whereas the current study deals with between-cow effects. Another study, which included 40 cows on one research farm and covered just over 1 yr (Hamann and Halm, 2004), showed the lowest SCC for milking intervals between 6 and $8 \mathrm{~h}$ and a nonlinear relationship between SCC and milking interval. Furthermore, unpublished data revealed that a high variation in milking interval was associated with 
elevated SCC (Svennersten-Sjaunja and Pettersson, 2008). Factors that may influence udder health through milking intervals could be the total machine-on time (teat damage and risk of bacterial invasion during and after milking), clearance of pathogens from the udder when milking more frequently, and more pressure on the udder when intervals become too long. Hogeveen et al. (2001) discussed these issues as well, but could not draw conclusions on the effect of milking interval on udder health from their data and suggested that a study with a large number of cows from different farms was necessary. Because AMS are used on a considerable number of dairy farms in the Netherlands, it was possible to obtain a large data set with SCC data and milking details from which intervals could be extracted.

The aim of this study was to explore whether milking interval or its variation is related to SCC, even when corrected for known effects of production, lactation stage, and parity (e.g., Schepers et al., 1997).

\section{MATERIALS AND METHODS}

\section{Data Collection}

Data from 151 farms were collected from May until October 2008 (Dohmen et al., 2010). Farms that were milking with an AMS for more than 1 yr and participated in the Dutch DHI scheme (CRV, Arnhem, the Netherlands) were visited for an inquiry and onfarm assessments. Historical data from the AMS, as available from the AMS management computer, was collected during the visit and, for most AMS farms, comprised data of the last $4 \mathrm{wk}$. These data included date, time, cow ID, and milk production of every milking. Data on SCC and cow information, like parity and calving date, came from the DHI test-day records collected every 4 to 6 wk routinely on the farms. Because visit dates were not matched to test-day dates, this resulted in different lengths of history of AMS data for a test day. Milk samples for the test-day records were collected using an automatic-sampling device that was connected to the AMS on one day and disconnected on the next day, which resulted in a sampling period of between 20 and $24 \mathrm{~h}$. When more than 1 sample for a cow were collected, samples were analyzed separately and the weighted average (against kilograms of milk) was reported as test-day SCC (C. van der Linde, CRV, Arnhem, the Netherlands, personal communication). The test-day date, used to match the data sets (see Data Processing), refers to the second sampling day.

\section{Data Processing}

Data from the AMS were available for 145 out of 151 farms. Two farms lacked test-day records and another
12 farms did not have a test day within the available period of AMS data for that farm, and were, therefore, excluded from further analysis. Furthermore, 1 farm seemed to have had problems with the AMS on the test day, resulting in many milkings with less than $1 \mathrm{~kg}$ of milk and 1 farm had a period of $51 \mathrm{~h}$ without milkings just before the test day. On another farm, it was noted in the data set that it was milking with a conventional system as well and 4 farms were milking with AMS for $<1$ yr. These 7 farms were excluded as well. When less than $10 \mathrm{~d}$ of history were available, the record was not used in further analyses, which resulted in excluding cows in the first $10 \mathrm{~d}$ of lactation and 24 complete farms where the matched test day was within the first $10 \mathrm{~d}$ of AMS data. The final data set, therefore, consisted of data from 100 farms. Farm characteristics like farm size, production level, and bulk tank SCC, were similar for the 51 excluded and 100 retained farms, as tested with the Wilcoxon 2-sample test. Therefore, it can be concluded that these 100 farms are representative of the whole sample of 151 farms, although the 2 farms with the smallest herd (both 30 cows) and the 1 with the largest herd (420 cows) were not included in the final data set (Table 1).

The 100 retained farms had 8,208 cows of which at least 1 record of AMS data was available. Two hundred and twenty-three cows from 50 farms could not be matched to a test-day record because cow identification numbers did not match. The AMS data of 561 cows from 85 farms did not have matching test-day records due to drying-off. For 14 cows on 8 farms, the lactation stage could not be determined because the calving date was missing. Seven cows on 1 farm had a parity number that was obviously too high (56 or 57). Furthermore, 835 cows with more than 350 DIM were excluded to make sure that all cows were of the recorded parity and no errors with respect to parity could be introduced due to missing calving dates. Furthermore, all fresh cows (217 from 78 farms) were excluded from the analyses when they had less than $10 \mathrm{~d}$ of milking history in the current lactation. The final data set, therefore, contained 6,351 cow records.

Because only about 4 wk of AMS data were available for most farms, only 1 test day fell within this period. For some farms, however, a longer period of AMS data was available. In those cases, only 1 test day was used in the final analysis. In general, test-day records were matched with AMS data only when AMS data were available for the day before the test-day date. For those farms where more than 1 test day could be matched with AMS data, the one with the longest available history of AMS data was used. In the rare case that more than 1 test day had more than $30 \mathrm{~d}$ of AMS data history, the one closest to the visiting date was used. 
Table 1. Farm size, production level, and bulk tank SCC of the farms in the original and final data set

\begin{tabular}{|c|c|c|c|c|c|c|}
\hline Description & $\mathrm{n}^{1}$ & Median & Mean & $\mathrm{SD}$ & Minimum & Maximum \\
\hline \multicolumn{7}{|l|}{ Original data set } \\
\hline Number of cows & 151 & 75 & 84 & 39 & 30 & 420 \\
\hline Quota $(1,000 \mathrm{~kg})$ & 148 & 700 & 798 & 446 & 154 & 5,000 \\
\hline Bulk tank SCC (1,000 cells $/ \mathrm{mL})$ & 150 & 220 & 234 & 86 & 46 & 550 \\
\hline \multicolumn{7}{|l|}{ Final data set } \\
\hline Number of cows & 100 & 73 & 81 & 28 & 38 & 150 \\
\hline Bulk tank SCC (1,000 cells $/ \mathrm{mL})$ & 99 & 204 & 230 & 88 & 46 & 520 \\
\hline
\end{tabular}

${ }^{1}$ We lacked information on quota or bulk tank SCC for some farms.

Milking intervals $(\mathrm{h})$ and milk production rate $(\mathrm{kg} / \mathrm{h}$; amount of milk divided by milking interval) were calculated for all available milkings. Data of all milkings (with more than $0 \mathrm{~kg}$ of milk) on a certain day were used to calculate the average and coefficient of variation of milking intervals and average production rate for that day. Averages over a $10-$ to $30-\mathrm{d}$ period (dependent on availability of AMS data history) were used to depict the long-term production rate of a cow, whereas average data of up to $3 \mathrm{~d}$ were used to model the short-term effect. As the correlation between longterm and short-term production rates was high, the difference between both was used in the analysis, next to the short-term production rate. For milking interval, only the short-term effect was used; for the variation in milking intervals, only the long-term effect was used. Information on parity and calving date, which was used to calculate DIM, was derived from DHI records. As the effect of most variables on SCC was not linear, all variables were transformed to class variables in such a way that variation in SCC between classes was as large as possible without creating classes with too few records (Table 2). Classes that could be expected to have the lowest SCC were selected as the reference class for most variables. For the variables production rate and difference in production rate, the majority class was used as reference class.

\section{Statistical Analysis}

Univariable and multivariable analyses were used to estimate the effect of milking interval on SCC, while correcting for cow and farm characteristics. The $\log 10$ of SCC was chosen as the dependent variable to ensure normal distribution of residuals. Cow characteristics were taken into account by fixed effects, whereas farm was included in the model as a random effect (linear mixed model with maximum likelihood estimation of covariance parameters). Only interactions that were thought to be biologically relevant were included, which resulted in the following basic model:

$$
\begin{gathered}
Y_{i j k l m n p}=\mu+\text { Int }_{i}+\text { CVInt }_{j}+\text { Prod }_{k}+\text { ProdDif }_{l} \\
+ \text { Par }_{m}+\text { DIM }_{n}+\text { Int }_{i} \times \text { CVInt } \\
+
\end{gathered}
$$

where $Y_{i j k l m n}$ is the $\log 10$-transformed SCC, $\mu$ is the intercept, Int $t_{i}$ is the short-term milking interval, CVInt $_{j}$ is the long-term coefficient of variation of milking interval, $\operatorname{Prod}_{k}$ is the short-term production rate, ProdDif is the difference in production rate between short- and long-term, $\mathrm{Par}_{m}$ is parity, DIM ${ }_{n}$ is DIM, Farm $_{p}$ is the random farm effect, and $\varepsilon_{i j k l m n}$ is the residual error term. The number of classes and range per class are given in Table 2 for all variables.

Starting from the full model with all main effects and stated interactions (see formula above), nonsignificant interactions were removed by manual backward elimination. When all nonsignificant $(P>0.05)$ interactions were removed, single variables that were not part of an interaction (in the selected model) and did not contribute significantly were removed as well.

All data preparation and statistical analyses were performed using SAS 9.2 software (SAS Institute Inc., Cary, NC).

\section{RESULTS AND DISCUSSION}

As calculating short-term effects over 2 or $3 \mathrm{~d}$ did not improve results compared with $1 \mathrm{~d}$ (the Akaike information criterion of the full model differed by less than $0.25 \%$ ), results are shown for 1-d short-term variables only.

Variation in milking intervals between the farms was quite large, ranging from 7.5 to $12.4 \mathrm{~h}$, which corresponds with a farm average milking frequency of less than 2 to more than 3 milkings per cow per day. Eight percent of the farms had an average milking interval of less than $8 \mathrm{~h}$ and $4 \%$ had an average milking interval of more than $11 \mathrm{~h}$. Within farms, the coefficient of varia- 
Table 2. Description of the variables, the range of its classes, and percentage of records in each class

\begin{tabular}{|c|c|c|c|}
\hline Variable name & Class & Range & $\begin{array}{l}\text { Percentage } \\
\text { of records }\end{array}$ \\
\hline Milking interval (h) & $\begin{array}{l}1 \\
2^{1} \\
3 \\
4 \\
5\end{array}$ & $\begin{aligned}<6 \\
\quad 6-9 \\
9-12 \\
12-15 \\
\geq 15\end{aligned}$ & $\begin{array}{r}5.5 \\
47.6 \\
29.4 \\
13.0 \\
4.6\end{array}$ \\
\hline CV of milking interval (\%) & $\begin{array}{l}1^{1} \\
2 \\
3 \\
4\end{array}$ & $\begin{array}{l}<12 \\
12-24 \\
24-36 \\
\geq 36\end{array}$ & $\begin{array}{r}5.9 \\
57.1 \\
31.1 \\
5.9\end{array}$ \\
\hline Production rate $(\mathrm{kg} / \mathrm{h})$ & $\begin{array}{l}1 \\
2 \\
3^{1} \\
4 \\
5\end{array}$ & $\begin{aligned} &<0.6 \\
& 0.6-1.0 \\
& 1.0-1.4 \\
& 1.4-1.8 \\
& \geq 1.8\end{aligned}$ & $\begin{array}{r}4.8 \\
26.0 \\
38.0 \\
23.8 \\
7.5\end{array}$ \\
\hline Difference in production rate $(\mathrm{kg} / \mathrm{h})$ & $\begin{array}{c}-2 \\
-1^{1} \\
1 \\
2\end{array}$ & $\begin{aligned}<-0.2 \\
\quad-0.2-0.0 \\
\quad 0.0-0.2 \\
\geq 0.2\end{aligned}$ & $\begin{array}{r}3.8 \\
52.4 \\
39.7 \\
4.1\end{array}$ \\
\hline DIM & $\begin{array}{l}1 \\
2^{1} \\
3\end{array}$ & $\begin{array}{c}10-30 \\
31-100 \\
101-350\end{array}$ & $\begin{array}{r}6.7 \\
19.4 \\
74.0\end{array}$ \\
\hline Parity & $\begin{array}{l}1^{1} \\
2 \\
3 \\
4 \\
5\end{array}$ & $\begin{array}{r}1 \\
2 \\
3 \\
4 \\
\geq 5\end{array}$ & $\begin{array}{l}30.7 \\
27.7 \\
18.5 \\
11.1 \\
12.1\end{array}$ \\
\hline
\end{tabular}

${ }^{1}$ Class used as reference class in the models.

tion of the milking intervals was not correlated with the average of the milking interval (Figure $1 ; \mathrm{r}=-0.03, P$ $=0.80)$.

Univariable analyses showed that all 6 variables, milking interval, coefficient of variation of milking interval, production rate, difference in production rate, parity, and DIM, were related to SCC (Table 3). Higher SCC could be seen with longer intervals, more variable milking intervals, lower production rates, strong production losses, in late lactation, and in higher-parity cows (Table 4). Increasing SCC with longer intervals is in accordance with Hamann and Halm (2004), whereas the increase in SCC with very short intervals $(<6 \mathrm{~h})$, as found by them, was not present in our data. This could be due to the low number of records (5.5\%; Table 2) with milking intervals of less than $6 \mathrm{~h}$ in our data set. Increasing SCC with more variable intervals (Svennersten-Sjaunja and Pettersson, 2008) is confirmed by our data as well.

When all 6 variables were included in a model (without interactions) it was most striking that the relationship between SCC and milking interval-the main variable of interest - was much weaker (lower $F$-value; Table 3$)$. However, an increase in SCC with very short milking intervals (Hamann and Halm, 2004), although weak, seemed to appear. Also the relationship with DIM and the coefficient of variation of milking interval was weaker. The relationship between SCC and production difference weakened and changed in such a way that not only high production losses were related to higher SCC, but also strong production increases (Table 4). The relationships between SCC on the one hand and parity and production level on the other hand remained strong and still pointed in the same direction (Table 4). Results of the final model showed that none of the interactions significantly contributed to the model, whereas all main effects did.

The effect of milking interval was, although significant, not very strong. The $F$-value of milking interval was the lowest one for a single variable (Table 3 ). This shows that the effect of milking interval on SCC is marginal when corrected for the other variables. The variation in milking intervals was positively related with SCC in the final model, showing that the variation in milking interval is even more important than the milking interval itself. Here, however, questions arise whether this variation is cause or effect. Is an increased SCC caused by an irregular visiting pattern or will cows with 
Table 3. Type 3 tests for fixed effects of univariable mixed models and in a multivariable mixed model without interactions

\begin{tabular}{|c|c|c|c|c|}
\hline \multirow[b]{2}{*}{ Variable } & \multicolumn{2}{|c|}{ Univariable } & \multicolumn{2}{|c|}{ Multivariable } \\
\hline & $F$-value & $P$-value & $F$-value & $P$-value \\
\hline Milking interval & 50.8 & $<0.001$ & 3.1 & 0.013 \\
\hline CV of milking interval & 31.0 & $<0.001$ & 10.8 & $<0.001$ \\
\hline Production rate & 70.2 & $<0.001$ & 51.9 & $<0.001$ \\
\hline Difference in production rate & 38.9 & $<0.001$ & 12.1 & $<0.001$ \\
\hline DIM & 40.2 & $<0.001$ & 4.7 & 0.010 \\
\hline Parity & 113.5 & $<0.001$ & 146.5 & $<0.001$ \\
\hline
\end{tabular}

an elevated SCC, which is an indication of (sub)clinical mastitis, show a more irregular visiting pattern due to feeling ill? This question cannot be answered by this analysis, but needs to be answered to be able to assess the use of this finding. When irregular visiting behavior is an indication of (sub)clinical mastitis, it may be used in detection algorithms, but when it induces high SCC, attention needs to be paid to management measures to make visiting patterns more regular.

A higher production rate was associated with a lower SCC, which could be explained by the already known dilution effect (Schepers et al., 1997; Green et al., 2006). The difference in production rate between the 30-d average and the current showed that SCC was higher when a strong increase or decrease in milk production occurred $(>0.2 \mathrm{~kg} / \mathrm{h}$ more or less; Table 4). The clear increase in SCC with DIM (especially for $>100$ DIM), as shown in the univariable model (Table
4), partly disappeared in the multivariable model. This effect is also shown by the decrease in $F$-value between the univariable and multivariable model (Table 3). The univariable effect of DIM on SCC can be explained by the (nonlinear) relationship between DIM and milk production, which follows a pattern that is inversely related to the shape of the milk production curve (Schepers et al., 1997). When both milk production and DIM are included in a model, it appears that milk production rate is the predominant factor. The effect that SCC increased with parity is well known (e.g., Schepers et al., 1997).

Performing a study on 100 farms gave us the opportunity to test whether effects found in more controlled circumstances are sustained in practice. When choosing for such a high number of farms, it is not possible to collect detailed and controlled data, so we had to rely on available on-farm data. This, of course, will intro-

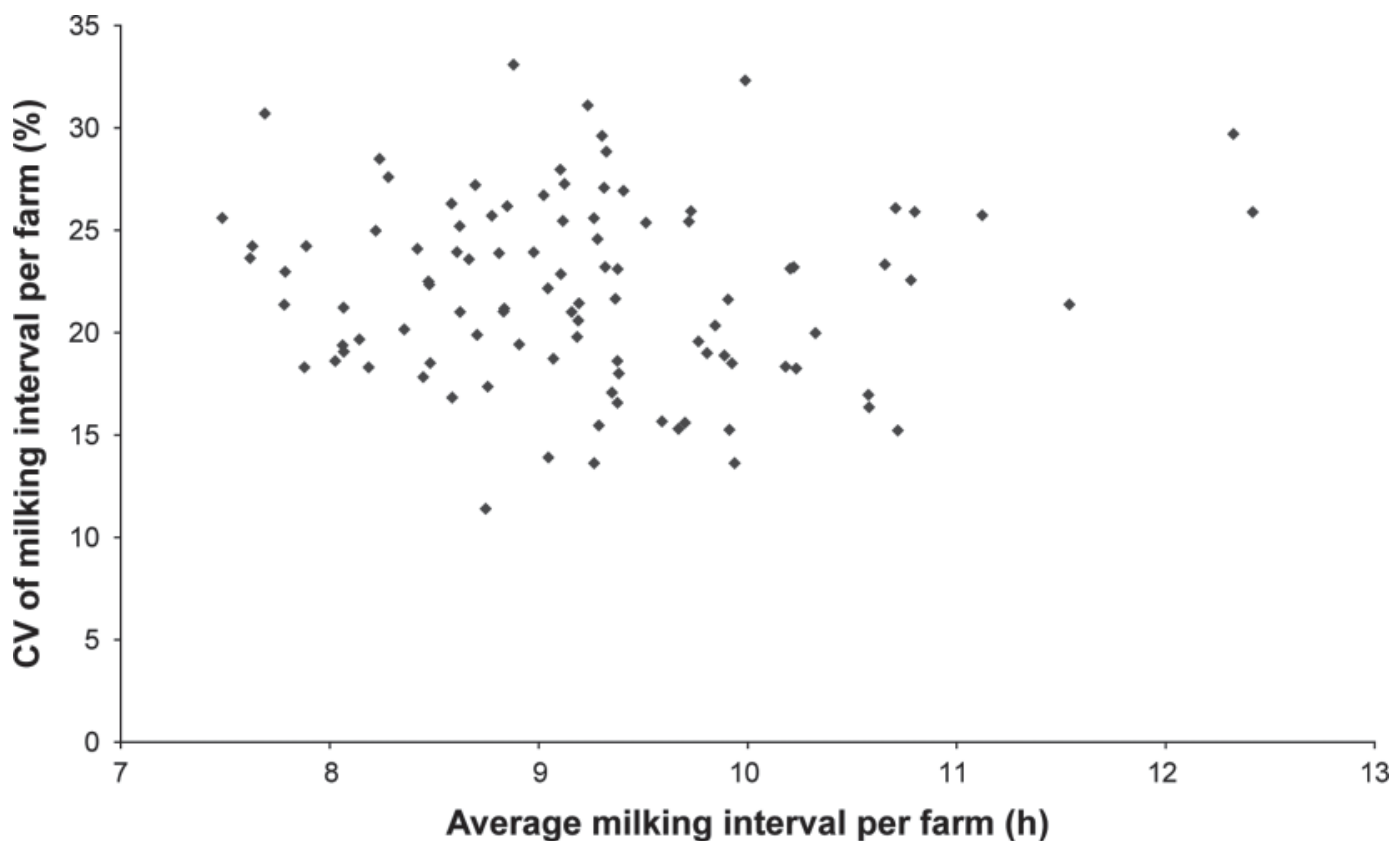

Figure 1. Scatter plot of the coefficient of variation of milking intervals within farms against the average milking interval per farm. 
Table 4. Parameter estimates for fixed effects of univariable mixed models and of a multivariable mixed model without interactions for log 10 SCC with data with 1-d history

\begin{tabular}{|c|c|c|c|c|c|}
\hline Variable name & Class & \multicolumn{2}{|c|}{ Univariable } & \multicolumn{2}{|c|}{ Multivariable } \\
\hline $\begin{array}{l}\text { Intercept } \\
\text { Milking interval (h) }\end{array}$ & $\begin{array}{l}1 \\
2^{1} \\
3 \\
4 \\
5\end{array}$ & $\begin{array}{c}1.92 \\
-0.03 \\
0 \\
0.13 \\
0.23 \\
0.30\end{array}$ & $\begin{array}{l}0.02 \\
0.03 \\
- \\
0.02 \\
0.02 \\
0.03\end{array}$ & $\begin{array}{l}1.74 \\
0.03 \\
0 \\
0.04 \\
0.07 \\
0.03\end{array}$ & $\begin{array}{l}0.03 \\
0.03 \\
- \\
0.02 \\
0.02 \\
0.03\end{array}$ \\
\hline $\begin{array}{l}\text { Intercept } \\
\text { CV of milking interval (\%) }\end{array}$ & $\begin{array}{l}1^{1} \\
2 \\
3 \\
4\end{array}$ & $\begin{array}{l}1.89 \\
0 \\
0.07 \\
0.16 \\
0.31\end{array}$ & $\begin{array}{l}0.03 \\
\overline{0} \\
0.03 \\
0.03 \\
0.04\end{array}$ & $\begin{array}{l}0 \\
0.03 \\
0.07 \\
0.18\end{array}$ & $\begin{array}{l}- \\
0.03 \\
0.03 \\
0.04\end{array}$ \\
\hline $\begin{array}{l}\text { Intercept } \\
\text { Production rate }(\mathrm{kg} / \mathrm{h})\end{array}$ & $\begin{array}{l}1 \\
2 \\
3^{1} \\
4 \\
5\end{array}$ & $\begin{array}{c}1.99 \\
0.39 \\
0.08 \\
0 \\
-0.08 \\
-0.16\end{array}$ & $\begin{array}{l}0.02 \\
0.03 \\
0.02 \\
- \\
0.02 \\
0.03\end{array}$ & $\begin{array}{c}0.29 \\
0.08 \\
0 \\
-0.13 \\
-0.27\end{array}$ & $\begin{array}{l}0.03 \\
0.02 \\
- \\
0.02 \\
0.03\end{array}$ \\
\hline $\begin{array}{l}\text { Intercept } \\
\text { Difference in production rate }(\mathrm{kg} / \mathrm{h})\end{array}$ & $\begin{array}{c}-2 \\
-1^{1} \\
1 \\
2\end{array}$ & $\begin{array}{c}2.02 \\
0.29 \\
0 \\
-0.08 \\
-0.03\end{array}$ & $\begin{array}{l}0.02 \\
0.03 \\
- \\
0.01 \\
0.03\end{array}$ & $\begin{array}{l}0.17 \\
0 \\
-0.01 \\
0.11\end{array}$ & $\begin{array}{l}0.03 \\
\overline{0.01} \\
0.04\end{array}$ \\
\hline $\begin{array}{l}\text { Intercept } \\
\text { DIM }\end{array}$ & $\begin{array}{l}1 \\
2^{1} \\
3\end{array}$ & $\begin{array}{l}1.89 \\
0.02 \\
0 \\
0.14\end{array}$ & $\begin{array}{l}0.02 \\
0.03 \\
\overline{0.02}\end{array}$ & $\begin{array}{l}-0.08 \\
0 \\
0.01\end{array}$ & $\begin{array}{l}0.03 \\
0.02\end{array}$ \\
\hline $\begin{array}{l}\text { Intercept } \\
\text { Parity }\end{array}$ & $\begin{array}{l}1^{1} \\
2 \\
3 \\
4 \\
5\end{array}$ & $\begin{array}{l}1.84 \\
0 \\
0.11 \\
0.22 \\
0.34 \\
0.38\end{array}$ & $\begin{array}{l}0.02 \\
\overline{0} \\
0.02 \\
0.02 \\
0.02 \\
0.02\end{array}$ & $\begin{array}{l}0 \\
0.16 \\
0.29 \\
0.40 \\
0.43\end{array}$ & $\begin{array}{l}- \\
0.02 \\
0.02 \\
0.02 \\
0.02\end{array}$ \\
\hline
\end{tabular}

${ }^{1}$ Class used as reference class in the models.

duce noise (for example, due to the way SCC samples were collected and analyzed), but, on the other hand, is much more representative of the real world situation. Furthermore, due to the large data set, we had the opportunity to test whether the effect of milking interval would hold when production level, lactation stage, and parity were included in the model. We concluded that including these variables in the model largely eliminated the effect of milking interval. In the end, only a limited association was shown between milking interval and SCC when milking with an AMS.

\section{ACKNOWLEDGMENTS}

This research is supported by the Dutch Technology Foundation (STW, Utrecht, the Netherlands), Applied Science Division of the Netherlands Organization for Scientific Research (NWO, The Hague, the Nether- lands), and the Technology Program of the Ministry of Economic Affairs, Agriculture and Innovation (The Hague, the Netherlands).

\section{REFERENCES}

Allen, D. B., E. J. DePeters, and R. C. Laben. 1986. Three times a day milking: Effects on milk production, reproductive efficiency, and udder health. J. Dairy Sci. 69:1441-1446.

Dohmen, W., F. Neijenhuis, and H. Hogeveen. 2010. Relationship between udder health and hygiene on farms with an automatic milking system. J. Dairy Sci. 93:4019-4033.

Fernando, R. S., and S. L. Spahr. 1983. Effects of milking interval on selected milk constituents from normal and infected quarters. J. Dairy Sci. 66:1155-1161.

Friggens, N. C., and M. D. Rasmussen. 2001. Milk quality assessment in automatic milking systems: Accounting for the effects of variable intervals between milkings on milk composition. Livest. Prod. Sci. 73:45-54.

Green, L. E., Y. H. Schukken, and M. J. Green. 2006. On distinguishing cause and consequence: Do high somatic cell counts lead to lower milk yield or does high milk yield lead to lower somatic cell count? Prev. Vet. Med. 76:74-89. 
Hamann, J., and H. Halm. 2004. Influence of varying milking intervals on milk composition-A physiological approach on secretion of "normal milk". Pages 215-220 in Automatic Milking: A Better Understanding: Proc. of the International Symposium, Lelystad, the Netherlands. Wageningen Academic Publishers, Wageningen, the Netherlands.

Hogeveen, H., W. Ouweltjes, C. J. A. M. de Koning, and K. Stelwagen. 2001. Milking interval, milk production and milk flow-rate in an automatic milking system. Livest. Prod. Sci. 72:157-167.

Neijenhuis, F., G. H. Klungel, and H. Hogeveen. 2001. Recovery of cow teats after milking as determined by ultrasonographic scanning. J. Dairy Sci. 84:2599-2606.

Nielsen, N. I., T. Larsen, M. Bjerring, and K. L. Ingvartsen. 2005. Quarter health, milking interval, and sampling time during milking affect the concentration of milk constituents. J. Dairy Sci. 88:3186-3200.
Österman, S., K. Östensson, K. Svennersten-Sjaunja, and J. Bertilsson. 2005. How does extended lactation in combination with different milking frequencies affect somatic cell counts in dairy cows? Livest. Prod. Sci. 96:225-232.

Schepers, A. J., T. J. G. M. Lam, Y. H. Schukken, J. B. M. Wilmink, and W. J. A. Hanekamp. 1997. Estimation of variance components for somatic cell counts to determine thresholds for uninfected quarters. J. Dairy Sci. 80:1833-1840.

Stelwagen, K., and S. J. Lacy-Hulbert. 1996. Effect of milking frequency on milk somatic cell count characteristics and mammary secretory cell damage in cows. Am. J. Vet. Res. 57:902-905.

Svennersten-Sjaunja, K. M., and G. Pettersson. 2008. Pros and cons of automatic milking in Europe. J. Anim. Sci. 86:37-46. 